\title{
The correlation between self regulated and learning achievement of underachiever students
}

\section{Syahniar}

Universitas Negeri Padang, Padang-Indonesia, (syahniar@konselor.org)

\begin{abstract}
This research is conducted based on the fact that underachiever students are still found in the field students whose intelligence is high but their learning outcomes are below standard. Self regulated is assumed as a factor exerting an influence upon underachiever students' learning achievement. The aim of this research is to see the correlation between self regulated and learning achievement of the underachievers. This research is classified into quantitative study which was conducted by applying correlational method. The subjects of the research were 87 students. The instruments used is self regulated instruments by applying scale of Likert model. The data obtained were analyzed by using simple regression. The results of the research indicate that there is a positive and significant correlation between self regulated and learning achievement of the underachievers.
\end{abstract}

Keywords: self regulated, learning achievement, underachiever students

\section{Introduction}

One of the indicators of the students' success in learning is their learning achievement (Winkel: 1997, Hamdu\&Agustina: 2011, Saefullah: 2012). The achievement is obtained through the teacher's assessment on the results of the subjects test called raport. Wilson (2011) explains that learning achievement refers to the level of the students' achievement in all subject areas as indicated by the results of standard achievement tests.

The achievement achieved by students certainly cannot be separated from several factors that come either from in or outside of the individual him or herself. Saefullah (2012) explains the factors affecting learning achievement can be classified into two groups, namely internal factors and external factors. Internal factors consist of intelligence, talent, interest, motivation, maturity, and readiness. Meanwhile external factors consist of family, school, and society. Based on these explanations, it is identified that one of the factors that could affect student achievement is the level of intelligence quotient (IQ).

Khodijah (2014: 101) proposes that "The IQ of a person is believed to have a profound effect on the success of his achievement". This idea suggests that the students who have higher intelligence scores would get higher academic value, enjoy school more, be better in the subjects taught, and in later life tend to get success. Even according to most experts, IQ is the main capital to achieve optimal results in learning. Therefore, students having high IQ should have high achievement in accordance with 
their potential. Unfortunately, in reality, not all of students with high IQ get high achievement. They are known as underachievers. Underachiever itself occurs when there is a discrepancy between the achievement and the result of the IQ test (Atiyah, S. (2011, Rahmawati, 2013, Pratama\&Suharni, 2017).

Underachiever phenomena are illustrated in several studies. Surya (1979) finds that there are 32 underachievers of 78 students classified as having high ability. Furthermore, the results of the research conducted by Sofiyanita (2003) indicate that there are 5 underachievers of 54 students attending superior class. In addition, Sahrul (2004) reports that by comparing the results of the IQ test and the students' learning achievement, 43 students are identified as underachievers.

The underachiever-related phenomena are also strengthened by the results of a preliminary study showing that there are 92 students whose learning achievement is not in accordance with their potential IQ should be. The results of these studies share that although the number of underachiever students varies considerably, it is believed that in every school, those achieving learning outcomes that are inconsistent with their potential will always appear.

One of the factors assumed to be related to learning achievement of underachiever students is self regulated. McCaslim\& Hickey (2001) state that "student achievement learning environments has been found to be influenced by the degree to which a student has effective use of self-regulation, or the ability of students to plan, monitor, and evaluate their own behavior, cognition and learning strategies". Self regulation has an important position in student academic achievement. Chen (2002) finds a significant relationship between self-regulated learning strategies and academic achievement. Self regulated learning has a very important role in the learning process and the achievement of learning outcomes (Shidiq\&Mujidin, 2009; Ghufron\&Risnawita, 2010).

Self regulated is necessary in terms of learning. Zimmerman and Ponds (2011) explain that metacognitive points for an individual to do self-management are planning, organizing, measuring, and instructing him or herself as needs during behavioral process. Students who are able to achieve their goals in learning are those who are able to regulate him or herself. Regarding to underachiever students, Reis (2000: 72) suggests that "underachiever students do not have good self-regulation skills"

Furthermore, McCoach\&Siegle (2003) argue that the factor that distinguishes underachiever and achiever students in improving their performance is the lack of self-regulation in underachiever students. Self- regulated is the ability of a person to direct his thoughts, feelings and behaviors to achieve goals systematically. Francis (2011) explains that long-term self-regulation has a relationship with school performance. The higher the level of the self-regulation, the better the students' adjustment and performance in the school environment is. In contrast, low self-regulation has a relation to low performance at school. Thus, self regulated should help underachiever students to achieve better at school.

Guidance and Counseling, as an integral part of education, is an effort to facilitate and establish students in order to achieve a complete and optimal development (Permendiknas No. 111 Tahun 2014). From the definition, it is revealed that the existence of Guidance and Counseling service has an important contribution in helping students to achieve learning outcomes which is an indicator of success in learning. Furthermore, the general purpose of the service is to help learners / counselees to achieve maturity and independence in life and carry out development tasks that include personal, social, learning, and career aspects as a whole optimally. Referring to these objectives, the learning achievement is a part of the concern of Guidance and Counseling service. Learning achievements and factors related to can be used as needs analysis in preparing Guidance and Counseling service programs in schools. 
Based on the above thoughts, the researcher is interested in examining the problems and designing a research intended to examine the correlation between self regulated and learning achievement of the underachiever students.

\section{Method}

This descriptive correlational research applied quantitative approach. The subjects of this research were 87 students. The sample was chosen by using Purposive Sampling technique. The instrument used to collect the data is isLikert Scale model. The results of the reliability test on the instrument showed that the score of the self regulated variable is 0.902 .The data obtained were analyzed by using simple regression.

\section{Result and Discussion}

Analysis requirement tests done in this research were normality test and linearity test.

1. Normality Test. The result of normality test shows that the Asymp. Sig. score of underachiever students' learning achievement is 0.319 , and that of students' self regulated is 0.182 .

2. Linearity Test. The result of linearity test shows that the value of F-calculated $(28,562)$ is higher that F-table (3.90) on significance level $0.000 \leq 0.05$.

The Correlation between SelfRegulated and Learning Achievement of Underachiever Students

Table 1. The Result of Simple Linear Regression Coefficient Test

\begin{tabular}{ccc}
\hline Model & $\mathbf{r}$ & $\mathbf{r 2}$ \\
\hline $\mathbf{X}-\mathbf{Y}$ & 0.517 & 0.267 \\
\hline
\end{tabular}

Table 1 presents that $\mathrm{r}$ value is 0.517 which indicates the coefficient of regression correlation between self regulated and learning achievement of underachiever students. Meanwhile the value of $\mathrm{r} 2$ is 0.267 suggesting that $26.7 \%$ variations of learning achievement are determined by self regulated, while the rest is affected by other variables.

The results of the research show that self regulated correlates positively and significantly to the learning achievement of underachiever students. The results also show that the relationship between self regulated and underachiever students' learning achievement is in "Average" category with correlational coefficient of 0,517. Furthermore, self regulated exerts $26.7 \%$ influence upon underachiever students' learning achievement. Thus, self regulated affects underachiever student learning achievement. Thus, the better the students' self regulated is, the higher the underachiever students' learning achievement will be.

Self regulated that consists of metacognitive, motivational and behavioral aspects has to be developed in order to improve students' learning achievement. The students who have self regulated are believed to be able to direct themselves to achieve learning goals. Hidayat, Nirwana and Syahniar(2016) propose that students who have good metacognitive, motivation, and behavior in conducting learning activities will tend to be autonomous in carrying out learning activities.

The purpose of self regulated is to regulate the personal resources, behaviors, and social environment (Gredler, 2011; Maulana, 2016). In other words, a self-regulated person sets his own goals, gives attention to his own behavior (self-observation), and compares his or her performance to the established goals (self-assessment) so as to obtain optimal learning outcomes 
Students who have self regulated can manage learning time well and use effective learning strategies to achieve learning goals. This is in accordance with the idea of Winne and Hadwin (2010) stating that students who have regulated are able to identify what they consider to be the conditions that define the assigned task, such as managing the time available, taking steps to achieve goals, and changing metacognitive knowledge to improve success in the present and future. Therefore, students must have good self regulated in order to obtain optimal learning achievement. The characteristics that a self-regulated learner must possess are: active, constructive, able to build his/her own meaning, able to set the goals, and able to make use of information strategies available in both internal environment (cognitive systems) and external environment (task conditions and learning context) (Boekaerts, in Quince, 2013)

Self regulated that consists of several points needs to be studied more deeply, for example the motivation. Children with high learning motivation generally will have a good learning achievement. Conversely those with low motivation would have unsatisfactorylearning achievement. Therefore, motivation is a power in a person characterized by an affective encouragement, and reactions to achieve the goals (Elmirawati, Daharnis, Syahniar, 2013).

Based on the above explanation, it is learned that underachiever students have to be able to develop their self regulated well in order to achieve optimal learning achievement. Not only in learning do the students need to apply self regulated but also in everyday life to achieve an effective life.

\section{Conclusion}

Based on the findings and the discussion, it can be concluded that there is a positive and significant correlation between self regulated and underachiever students' learning achievement. In other words, the better the self regulated is, the higher the underachiever students' learning achievement will be.

\section{References}

AR, N. A. N. (2015). Psikologi belajar. Al-Fikrah: Jurnal Kependidikan Islam, 6.

Atiyah, S. (2011). Upaya Konselor dalam Mengatasi Siswa Underachiever Di Sma An-Najiyah Surabaya(Doctoral dissertation, UIN Sunan Ampel Surabaya).

Chen, S.C. (2002). Self regulated learning strategies and achievement in an introduction to information system course. JournalSpring Vol. 20, No. 1.

Ford, Donna. Y. \& Thomas, A. (1997). Underachievement Among Gifted Minority Students : Problems and Promises. ERIC Digest E544.

Francis, N.P. (2011). Tinjauanteoritis: Self RegulationpadaMahasiswaUnderachiever. Humaniora.Vol.2, No.1.

Ghufron, M.N \&Risnawita R. (2010). Teori-teori Psikologi. Yogyakarta: Ar Ruzz Media.

Gredler, M. E. (2011). Learning and Instruction Teori dan Aplikasi (Edisi Keenam). Terjemahan oleh Tri Wibowo, B. S. Jakarta: Kencana Prenada Media Group.

Hamdu, G., \& Agustina, L. (2011). Pengaruh Motivasi Belajar Siswa Terhadap Prestasi Belajar IPA di Sekolah Dasar. Jurnal Penelitian Pendidikan, 12(1), 90-96.

Khodijah, N.(2014). Psikologi Pendidikan. Jakarta: Raja Grafindo Persada.

Maulana, Z. (2012). Meningkatkan Kemandirian Belajar Melalui Layanan Informasi pada Siswa Kelas XI IPS SMA 1 Tolangogula Kabupaten Gorontalo.Jurnal Ilmu Pendidikan PEDAGOGIKA, Vol. 3, No. (3), Hal. 1-17. 
McCaslin, M., \& Hickey, D.T. (2001). Self-regulated learning and academic achievement: A Vygotskian view. In B. J. Zimmerman \& D. H. Schunk (Eds.), Self-regulated learning and academic achievement: Theoretical perspectives (pp. 227-252). Mahwah, NJ: Erlbaum.

McCoach dan Siegle. (2003). Factors that Differentiate Underachieving Gifted Students from High Achieving Gifted Students. Jurnal Gifted Child Quarterly, Spring 2003 Vol. 47, No. 2.

Munandar, U. (2009). Pengembangan Kreativitas Anak Berbakat.Jakarta: Rineka Cipta.

Permendiknas Republik Indonesia Nomor 114 Tahun 2014 Tentang Bimbingan dan Konseling pada Pendidikan Dasar dan Menengah.2014. Jakarta: Menteri Pendidikan dan Kebudayaan Nasional.

Pratama, B. D., \& Suharni, S. (2017). Layanan Bimbingan dan Konseling dalam Mengatasi Siswa Underachiever. Counsellia: Jurnal Bimbingan dan Konseling, 7(1), 1-10.

Prayitno dan Erman, A. (2013). Dasar-dasar Bimbingan dan Konseling. Jakarta: Rineka Cipta.

Quince, B. C. R. (2013). The Effects of Self Regulated Learning Strategy Instruction and Structured Diary use on Students Self Regulated Learning Conduct and Academic Success in Online Comunity College General Education Courses. Disertasi (Online). University of San Francisco.

Rahmawati, R. (2013). Bimbingan dan Konseling untuk Anak Underachiever.Paradigma., 7 (14)

Reis, S. M. (2000). The Underachievement of Gifted Students: What Do We Know and Where Do We Go?.Jurnal Gifted Child Quarterly, Summer 2000 Vol. 44, No. 3, Hal.72-83.

Saefullah. (2012). Psikologi Perkembangandan Pendidikan.Bandung:Pustaka Setia.

Sahrul, T. (2004).ProfilSiswaUnderachieverdanLayananPembelajaranolehPembimbing di SMAN 2 Padang.Tesis. PPS UNP.

Santrock, J. W. (2010).Psikologi Pendidikan. Terjemahan oleh Tri Wibowo. Jakarta: Erlangga.

Sari, D.P. (2015). Efektivitas Layanan Bimbingan Kelompok untuk Meningkatkan Self Regulation Siswa dalam Belajar.Tesis. Padang: Program Studi S2 Bimbingan dan Konseling UNP Padang

Shidiq, A. D. N., dan Mujidin. (2009). Perbedaan Self Regulated Learning antara Siswa Underachievers dan Siswa Overachievers pada Kelas 3 SMPN 6 Yogyakarta.Jurnal Psikologi, Vol. 29. No. 1.

Sofiyanita.(2003). KondisiSiswaUnderachieverdan Layanan Pembelajaran oleh Guru Pembimbing di SMUN 1 Bukittinggi.Tesis. Padang: PPs UNP Padang.

Surya.M. (1979). Pengaruh Faktor-faktor Non-intelektual terhadap Gejala Berprestasi Kurang. Disertasi.IKIP Bandung.

Widyastuti, R. ( 2010). Hubungan Motivasi Belajar dan Hasil Tes Inteligensi dengan Prestasi Belajar. Tesis (Online). Program Pascasarjana Universitas Sebelas Maret Surakarta.

Wilson, M. L. (2011). Students Learning Style Preferences and Teachers InstructionalStrategies: Correlations between matchedStyles and academic achievement. Disertasi (Online). Liberty University Lynchburg.

Winne, P. H., dan Hadwin, A. F. (2010). Learning and Cognition: Theoretical perspectives learning. Canada: Elsevier ltd.

Winkel W.S. (1997). Psikologi Pendidikan dan Evaluasi Belajar. Jakarta: Gramedia.

Zimmerman, B. J., dan Schunk, D. H. (2011). Hanbook Self Regulation of Learning and Performance. New York dan London: Routledge Taylor dan Francis Group 